\title{
Rozwój przestrzenny wczesnośredniowiecznego Gdańska w świetle źródel archeologicznych
}

\section{Spatial development of early medieval Gdańsk in the light of archaeological sources}

Zarys treści: Artykuł jest próbą podsumowania dotychczasowego stanu badań archeologicznych w kontekście ustaleń dotyczących rozwoju przestrzennego wczesnośredniowiecznego Gdańska. W rozważaniach uwzględniono zarówno tezy oparte o rezultaty starszych badań, jak i efekty najnowszych prac wykopaliskowych, w tym nowe wyniki datowania grodu gdańskiego. W świetle dokonanych ustaleń Gdańsk wczesnośredniowieczny jawi się jako zespół osadniczy złożony z różnorodnych pod względem formy i funkcji elementów, które cechuje zarówno wieloczłonowość, jak i nieregularność układów przestrzennych.

Słowa kluczowe: Gdańsk, wczesne średniowiecze, architektura romańska.

Gdańsk jest położony nad Zatoką Gdańską w miejscu gdzie Motława uchodzi do Wisły, około 4,5 km od brzegu Morza Bałtyckiego. Zatoka ta jest odgrodzona od otwartego morza poprzez Półwysep Helski, który rozciąga się na długości ponad $30 \mathrm{~km}$, tworząc idealne warunki dla funkcjonowania portu morskiego. Aż do roku 1371 jedna z odnóg Wisły, znana jako Wisła Gdańska, płynęła w miejscu obecnej ulicy Wałowej i Karpiej. Tak więc od wschodu miasto było chronione przez Motławę, deltę Wisły i przez bagna Żuław, od południa zaś przez rzekę Radunię. Od zachodu wynosi się tutaj wysoczyzna Pojezierza Kaszubskiego ze znaczną liczbą cieków wodnych, formujących u jej podnóża aluwialne stożki. Cieki te stanowią doskonałe źródło czystej wody pitnej, a fakt, że spływają żwawym nurtem z dość znacznych wysokości, czyni je przydatnymi tak do celów obronnych, jak i gospodarczych. Zatem od zarania swego istnienia Gdańsk był świetnie ulokowany i dobrze chroniony, znajdując się w bezpiecznej odległości od morskiego wybrzeża, a przy tym leżąc na skrzyżowaniu kilku głównych szlaków lądowych, rzecznych i morskich, w miejscu doskonale zaopatrzonym w wodę pitną. 


\section{Grodzisko na „Zamczysku”}

Wczesnośredniowieczny gród gdański położony w widłach Motławy i Wisły (znany w literaturze jako stanowisko 1) został w 1. połowie XIV wieku w znacznym stopniu zniszczony w trakcie budowy zamku krzyżackiego, od czego ta część miasta otrzymała nazwę „Zamczysko". Najstarsze odkrycia miały tu miejsce w latach 20. XX wieku, kiedy w wykopach pod instalacje odkryto warstwy wczesnośredniowieczne, fragmenty murów zamkowych oraz późnośredniowieczne cmentarzysko. Po wojnie, w latach 1948-1954, prowadzono tu badania przy ulicy Rycerskiej 5 (wykopy I-V o powierzchni $325 \mathrm{~m}^{2}$ ), odsłaniając 17 poziomów zabudowy grodu, datowanych wówczas od około 980 do 1308 roku, tj. do zajęcia Gdańska przez Krzyżaków ${ }^{1}$. Nieopodal, przy ulicy Rycerskiej 13, natrafiono na ulicę o szerokości 5,5m, której nawierzchnia była umocniona drewnianymi bierwionami oraz usytuowanych nad nią sześć poziomów zabudowy, datowanych wówczas na okres od początku XI do końca XIII wieku (Lepówna 1967, s. 110-116; Barnycz-Gupieniec 1998, s. 6). Badaniami objęto też umocnienia grodu, zakładając wykop VIII przy ulicy Rycerskiej 14/14. Stwierdzono, że drewniano-ziemna konstrukcja wału została posadowiona na warstwach nie starszych niż XI-wieczne. W latach 1954-1961 odsłonięto i zadokumentowano relikty umocnień brzegowych oraz konstrukcje pomostów związanych z funkcjonowaniem portu, usytuowane po zachodniej i południowo-zachodniej stronie grodziska, między innymi przy ulicy Sukienniczej 8 (wykop XX), przy ulicy Obrońców Poczty Polskiej 1/2 (wykop XXI) oraz przy ulicy Grodzkiej 3-4, gdzie odkryto nie tylko wczesnośredniowieczne nabrzeża i pomosty, ale także pozostałości wałów oraz podwaliny baszty grodowej. Natrafiono też na relikty umocnień brzegowych związanych z portem nowo powstającej dzielnicy miasta (stanowisko 2), usytuowanych nad zbiornikiem wodnym pomiędzy ulicami Tartaczną, Sukienniczą i Placem Obrońców Poczty Polskiej otwartym od południa na Motławę, od północy zbierający wody cieku płynącego z wysoczyzny (Zbierski 1964, s. 188-192).

W opinii Janiny Kamińskiej jednoczłonowy gród był otoczony wałem, o szerokości u podstawy wynoszącej około $14 \mathrm{~m}$; zamykał on obszar o powierzchni około 2,25 ha $(165 \times 215 \mathrm{~m})$. Zamieszkiwała go ludność wolna, której dieta zawierała w większości zboża i mięso zwierząt hodowlanych, łowiąca ryby indywidualnie, trudniąca się także rzemiosłem. Wśród importów odkryto przedmioty pochodzące z Anglii, Fryzji, Flandrii, Nadrenii, Saksonii, Skandynawii, Prus, Rusi Kijowskiej i Bizancjum. Po zniszczeniu grodu przez Bolesława Krzywoustego ludność kupiecka i rzemieślnicza przeniosła się na podgrodzie (stanowisko 2), zaś w grodzie pozostali ludzie feudała (Kamińska 1955, s. 158-161). Z opinią J. Kamińskiej nie

${ }^{1}$ Badania te były prowadzone przez K. Jażdżewskiego (1958, s. 73-120) oraz Janinę Kamińską (1955) we współpracy z zespołem wielu archeologów i specjalistów innych dyscyplin. 

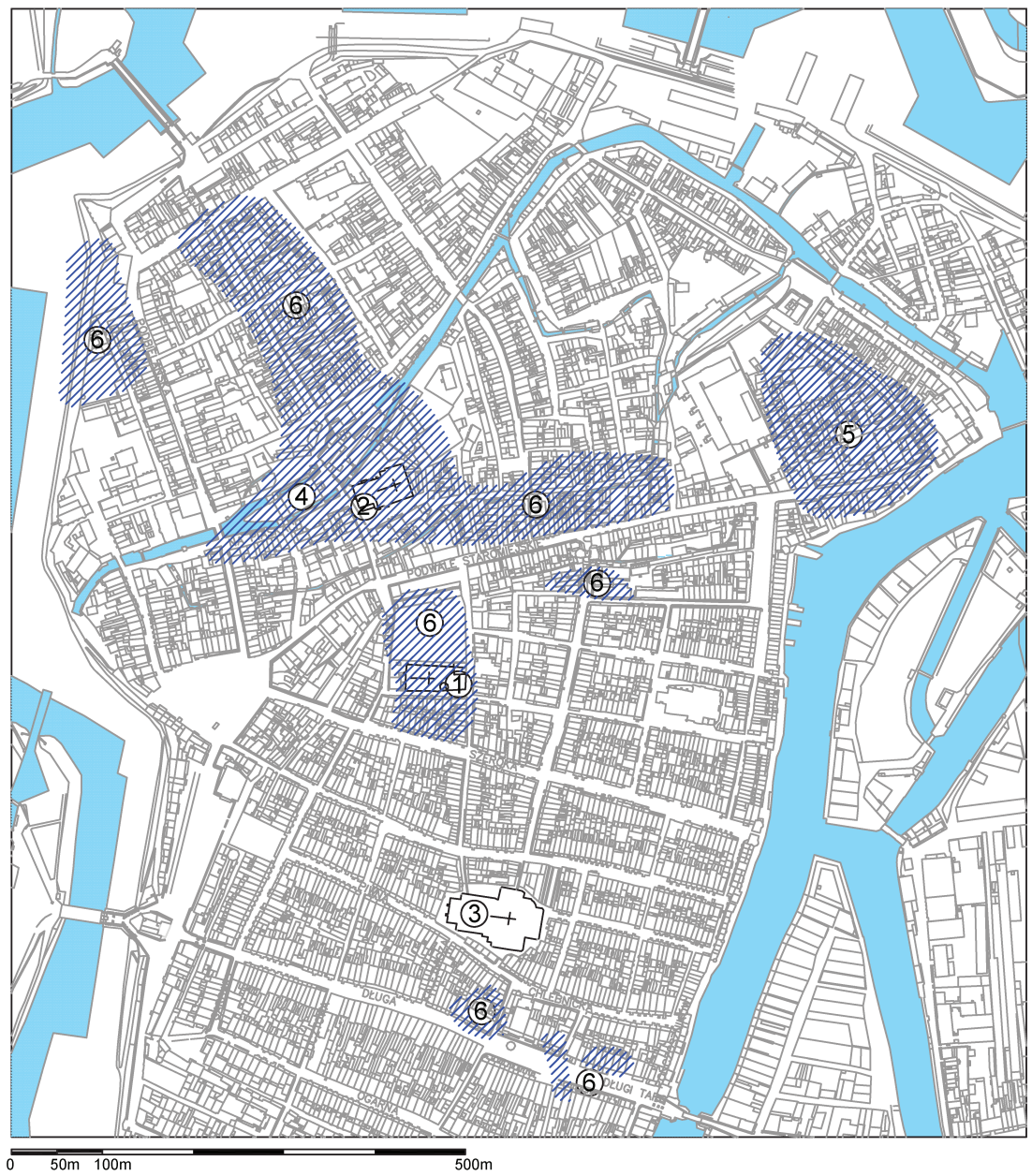

(1) Kościół św. Mikołaja

(2) Kościół św. Katarzyny

(3) Kościół Najświętszej Marii Panny

(4) Wielki Młyn

(5) Gród gdański st.1

(6) Osadnictwo wczesnośredniowieczne na obszarze Starego i Głównego Miasta

Ryc. 1. Wczesnośredniowieczne osadnictwo na terenie Gdańska (oprac. H. Paner, S. Moszczyński)

Fig. 1. Early medieval settlement in Gdańsk (prepared by H. Paner, S. Moszczyński) zgodził się Andrzej Zbierski, który uznał pozostałości fortyfikacji znalezione w wykopie VIII przy ulicy Rycerskiej 14/15 za część wałów: zewnętrznego i wewnętrznego. Ten ostatni miał otaczać od południowego wschodu siedzibę feudała castellum, podczas gdy wał zewnętrzny bronił od północy dzielnicy rybacko-rzemieślniczej. Zdaniem A. Zbierskiego, a następnie Barbary Lepówny 
oraz Romany Barnycz-Gupieniec, wyodrębniona siedziba feudała i dzielnica rybacka, a także regularne rozplanowanie zabudowy, czy powtarzalność jej planu, interpretowana jako dziedziczenie działek i warsztatów, świadczyły o miejskim charakterze Gdańska już od X wieku (Kmieciński 1955a, s. 233-237; Zbierski 1964, s. 325-328, plan 13; Lepówna 1967, s. 131; Barnycz-Gupieniec 1974, s. 104-105). W literaturze znalazło swój wyraz w wymiennym używaniu nazwy „gród” i ,miasto”.

Wyniki prac publikowano między innymi w periodyku „Studia Wczesnośredniowieczne” oraz w 10 tomach serii „Gdańsk Wczesnośredniowieczny”, seryjnego wydawnictwa Komisji Archeologicznej Gdańskiego Towarzystwa Naukowego. Znalazły się tam zarówno wyniki badań poszczególnych stanowisk, jak i opracowania dotyczące: garncarstwa (Lepówna 1967; 1968), szewstwa (Wiklak 1960, s. 7-104), bursztyniarstwa (Wapińska 1967, s. 83-99), budownictwa drewnianego (Byrska 1955, s. 217-232; Barnycz-Gupieniec 1974), rybołówstwa (Kmieciński 1955b; Rulewicz 1994), hutnictwa i kowalstwa (Piaskowski 1960), obróbki kości i poroża/rogu, bednarstwa i tokarstwa (Barnycz-Gupieniec 1961, s. 391-434), włókiennictwa (Kamińska, Nahlik 1958), złotnictwa (Hołowińska 1959, s. 55-105; 1960, s. 183-239), a także monet (Gupieniec 1963), zabawek i gier (Kunicka-Okuliczowa 1959, s. 107-143) oraz wyrobów szklanych (Chmielowska 1960, s. 105-157). Opracowano również kości zwierzęce (Jaworski 1952; Krysiak 1956; 1967, s. 7-51; Susłowska, Urbanowicz 1967, s. 53-65; Kubasiewicz 1977) oraz szczątki roślinne (Mądalski 1952; Lechnicki 1955, s. 252-259; Lechnicki, Klichowska, Gupieniec 1961, s. 5-25). Przeprowadzono też próbę synchronizacji stanowisk archeologicznych w oparciu o materiał ceramiczny (Lepówna 1967). Ogólne podsumowanie wyników badań stanowiska 1 zawarto w „Archeologia urbium” (1966) oraz kilka lat później w pierwszym tomie „Historii Gdańska” pod redakcją Edmunda Cieślaka (Zbierski 1978a, s. 71-125; 1978b, s. 194-223).

Niezależnie od stosunkowo wyczerpujących opracowań materiałowych, wiele wątpliwości zaczęły z czasem budzić interpretacje znalezisk, szczególnie związanych z rzemiosłem, czyli funkcjonowaniem na grodzie wyspecjalizowanych warsztatów rzemieślniczych. Ostatecznie po wieloletnich, niezwykle drobiazgowych studiach, R. Barnycz-Gupieniec uznała, że podstawowym zajęciem ludności gdańskiego grodu było rybołówstwo, zaś pozostałe zajęcia miały charakter uboczny i wykonywane były głównie na własne potrzeby. Badaczka potwierdziła też wcześniejsze przypuszczenia Konrada Jażdżewskiego o obowiązku służby zbrojnej tej ludności dla księcia, za czym mogą przemawiać znaleziska militariów (Barnycz-Gupieniec 2003, s. 13-14).

Wątpliwości budziło także zbyt wczesne datowanie materiałów ceramicznych i monet, a także uznanie, że czas trwania jednego poziomu osadniczego dla

${ }^{2} \mathrm{O}$ tendencjach w interpretacji wyników badań grodów wczesnośredniowiecznych pod kątem ich traktowania jako wczesne miasta - por. Moździoch 2002, s. 195. 
stanowiska 1 wynosił 25 lat (Łosiński 2001, s. 51-54). Doprowadziło to w roku 2003, z inicjatywy Bogdana Kościńskiego, do podjęcia próby datowania poziomów osadniczych na podstawie analiz drewna z konstrukcji odsłoniętych przy północnej części dawnego wykopu głównego, w wykopie o długości 14m (Kościński, Paner 2005 , s. 11-47) ${ }^{3}$. Z uzyskanych 29 dat, 14 pochodzi ze starszej fazy istnienia grodu, 1 z fazy środkowej oraz 14 z fazy młodszej. Najmłodszą datę $(1138+8 ;-6)$ uzyskano dla pogranicza poziomów 3 i 4, jako że w wyższych poziomach, ze względu na znaczny stopień destrukcji drewno nie nadawało się do analiz. Daty najstarsze, dla poziomu 16/17, obejmują lata 1062/1063 oraz 1089/1090 (Kościński, Paner 2005, s. 23). Ze względu na zaskakujący wynik analiz, zweryfikowano daty dendrochronologiczne, wykonując serię analiz radiowęglowych $\mathrm{C}^{14}$ dla prób nasion wyselekcjonowanych z mierzwy zalegającej w poziomach $4,6,10 / 11$ i $11^{4}$. $\mathrm{Na}$ tej podstawie terminus ante quem zbadanych poziomów ustalono na rok 1160, co potwierdziło ustalenia dokonane w oparciu o metodę dendrochronologiczną. Okazało się, że czas trwania poziomów, z których uzyskano daty bezwzględne, zamiast dotychczasowych 275 lat, wyliczonych według schematu trwania jednego poziomu od 10/15 do 25 lat, może wynosić zaledwie 80 lat, zatem czas przypadający na jeden poziom osadniczy wynosi zaledwie około 7 lat. Porównując wyniki uzyskane dla podgrodzia (wykopy I-V) z wynikami badań przeprowadzonych przez Andrzeja Gołębiewskiego we wschodniej części wału grodowego (por. niżej) można postawić tezę, że podgrodzie stanowiło późniejszy od fortyfikacji grodu etap rozbudowy tego ośrodka, związany z modernizacją wału grodowego od jego zewnętrznej strony dokonaną w latach 90. XI stulecia.

Podjęto też próby określenia chronologii wału w rejonie ulicy Rycerskiej 14-18, gdzie dla jego dolnej, izbicowej konstrukcji uzyskano daty 1052-1054, zaś dla wyższej, przekładkowej oraz części zewnętrznych daty 1080-1100. W opinii kierownika wspomnianych wyżej badań, A. Gołębiewskiego, ,[...] w latach 1052-1054 powstał niewielki gród otoczony wałem w konstrukcji skrzyniowej, naprawiany często w latach 60-tych tego stulecia" (Gołębiewski 2005a, s. 57). „Na początku lat 90. uległ on spaleniu. W roku 1097 powstał nowy pierścień wału od strony wschodniej, głębiej posadowiony i w konstrukcji rusztowej, okalający dopiero wtedy znaczny obszar z dzielnicą rzemieślniczo-rybacką. Starszy pierścień pozostawiono, wydzielając nim siedzibę feudała" (Gołębiewski 2005b, s. 345-347). Wnioski te poparli Henryk Paner i B. Kościński, stawiając tezę że tzw. wał wewnętrzny odkryty w wykopach VIII i XIV, postawiony na reliktach osadnictwa z X/XI wieku, mógł mieć związek z działaniami z czasów Bolesława

\footnotetext{
${ }^{3}$ Analizy wykonał Tomasz Ważny z Instytutu Zabytkoznawstwa i Konserwatorstwa Uniwersytetu Mikołaja Kopernika w Toruniu.

${ }^{4}$ Próby zostały pobrane przez Monikę Badurę z Katedry Ekologii Roślin Wydziału Biologii Uniwersytetu Gdańskiego, analizę wykonał Tomasz Goslar z Poznańskiego Laboratorium Radiowęglowego.
} 
Krzywoustego, po zajęciu przez jego wojska gdańskiego grodu (Kościński, Paner 2005, s. 27).

Z taką tezą natomiast nie zgodził się Zbigniew Polak, opierając się głównie na wynikach badań przy ulicy Grodzkiej 17, który stwierdził, że konstrukcyjna niejednorodność południowo-wschodniego odcinka grodowych umocnień nie może być dowodem na istnienie w tym miejscu wału broniącego siedziby feudała, jako że podobna niejednorodność cechuje także inne przebadane fragmenty wału grodowego, jak choćby umocnienia odkryte przy ulicy Grodzkiej 6-7 (Paner 2006, s. 18-19; Paner, Borcowski 1993, s. 85). Przytoczył również fakt, że żadnego podziału przestrzeni grodu nie stwierdzono $\mathrm{w}$ trakcie badań prowadzonych przy ulicach Grodzkiej 17/Rycerskiej 11, chociaż w jego opinii ten właśnie obszar powinien takich dowodów dostarczyć, jeśli teza o wydzielonym castellum jest prawdziwa. Cytowany badacz widział w tym miejscu niczym niezakłócony rozwój osadnictwa od około połowy XI wieku, bez śladów pożaru czy destrukcji, co rażąco odbiega od obrazu uzyskanego dla północnej części grodu (Polak 2009, s. 474)5. Jednocześnie zanegował miejski charakter opisywanego ośrodka, stwierdzając: „Gród nie był miastem, ale ośrodkiem organizacji gospodarczej i administracji państwowej, siedzibą urzędników, zamieszkiwaną głównie przez rycerstwo pospolite i ludność służebną" (Barański 1994, s. 91-99; Moździoch 2002, s. 217-218). ,Jego budowa była poważnym przedsięwzięciem logistycznym, decyzję o niej podejmował sam książę, a wykonywała w ramach obowiązkowej posługi ludność pospolita i rycerstwo ze znacznego obszaru" (Zajączkowski 2002, s. 399-427; Dąbrowski 2007, s. 53-86) ${ }^{6}$. Warto zauważyć, że w wykopie XIV pod wałem wydzielono trzy poziomy zabudowy mieszkalnej, środkowy, na podstawie monet Ottona III i Adelajdy, datowano na lata 992-995. Warstwy starsze niż zabudowa wnętrza grodu znaleziono też w wykopach przy ulicach Rycerskiej 13 i Grodzkiej 12. Warstwę kulturową pod wałem stwierdzono również w wykopie VIII, przy ulicy Rycerskiej 14/15. Przy ulicy Grodzkiej 19 pobrano 10 próbek drewna z najstarszych elementów rusztu oraz z dolnych partii skrzyń zachowanych do dziewięciu belek, z których uzyskano daty: 1051-1059 rok oraz 1061-1065 rok. Dla dostawionych do wału od strony rzeki skrzyń, pełniących funkcje pomostów otrzymano daty od 1101 do 1106 roku. Na podstawie odkryć z ulicy Grodzkiej 6-7 stwierdzono, że wał funkcjonował od połowy XI do lat 40. XIV wieku.

W świetle uzyskanych wyników budynki mieszkalne w północnej części grodu pojawiły się po 40 latach od zbudowania umocnień. Według najnowszych ustaleń R. Barycz-Gupieniec można tam wyróżnić trzy fazy. Najstarsza obejmuje okres od 1090 roku do początku lat 20. XII wieku. Odpowiadały jej poziomy od 16/17 do 13, w których nie stwierdzono gęstej zabudowy i moszczonych ulic. Kolejna

\footnotetext{
${ }^{5}$ Informacje ustne od Zbigniewa Polaka, za które uprzejmie dziękuję.

${ }^{6}$ Z. Polak, Grodzisko. Niepublikowane materiały opracowane do projektu pt. Atlas Historyczny Gdańska, red. W. Długokęcki, za których udostępnienie serdecznie dziękuję.
} 
faza - środkowa - datowana jest na 1. połowę lat 20. XII wieku. Związane z nią były poziomy 12 do 10; w poziomie 12 zamiast domów zrębowych odnotowano plecionkowe, w 11 ponownie zrębowe, zniszczone przez pożar z czasów Bolesława Krzywoustego (1116 rok?), w 10 zaś także plecionkowe. Najmłodszej fazie przypadającej na okres od początku lat 30 . XII wieku, odpowiadał poziom 9 , w którym stwierdzono moszczenie ulic, stabilizację zabudowy w konstrukcji zrębowej, a nawet domy wieloizbowe (Barnycz-Gupieniec 2003, s. 12-14). Na przełomie XII i XIII wieku osadnictwo to zostało zniszczone gwałtownym pożarem (Kościński, Paner 2005, s. 39-40).

Południowa część grodu mogła być zasiedlona nieco wcześniej, o czym świadczą znaleziska monet, jak już wspomniano, nie zanotowano tam również (w trakcie badań przy ulicach Grodzkiej 17/Rycerskiej 11/12) ani śladów gwałtownego pożaru, ani tymczasowej zabudowy plecionkowej, rozbiórki budynków czy destrukcji ulic. Stwierdzono natomiast podobieństwo w rozplanowaniu poszczególnych poziomów, co może świadczyć o stabilizacji osadnictwa. Tak więc zjawiska odnotowane w północnej części gdańskiego grodziska, nie znalazły - jak dotąd - potwierdzenia w jego południowej części. Wyjątkiem jest wspólne zubożenie w obu przypadkach inwentarza znalezisk datowanych od 2. ćwierci XII wieku, a także standaryzacja wyrobów garncarskich (Lepówna 1968, s. 171-173). Zdaniem Leszka Kajzera zmiana charakteru nawarstwień na przełomie XII i XIII wieku związana jest ze zmianą pełnionej przez gród funkcji (Kajzer 2003, s. 426). Jednocześnie powstały tu pierwsze obiekty murowane, w tym kościół pod wezwaniem NM Panny, wzniesiony w południowo-zachodniej części (Kajzer 2003, s. 426). Z obiektem tym kojarzone są zarówno płytki posadzkowe z poziomu 2, datowane na schyłek XII wieku (Lepówna 1967; Świechowski 2000, ryc. 272, 276, 294, 398), jak i baza kolumny romańskiej znalezionej przy ulicy Czopowej 15 (wykop X), aczkolwiek - jak dotąd - nie natrafiono na relikty tej świątyni. Natomiast w rejonie ulic Grodzkiej i Sukienniczej odkryto zapewne pozostałości cmentarza przykościelnego. Na groby natrafiono tu zarówno w latach międzywojennych, jak i w 1964 roku, kiedy to znaleziono dębowe trumny, luźne kości, jeden pochówek kobiety, trzy pochówki dzieci oraz granitowe płyty nagrobne zdobione krzyżem. W południowo-wschodniej części, zapewne w czasach Świętopełka, wzniesiono wieżę mieszkalno-obronną, wzmiankowaną w źródłach mówiących o zdobyciu gdańskiego grodu przez Bolesława Pobożnego w roku 1272 (Kajzer 2003, s. 433-436).

\section{Stare Miasto}

Jeszcze podczas badań prowadzonych w latach 60. XX wieku, w pobliżu ulicy Podwale Staromiejskie 57-59, zarejestrowano brzeg zbiornika wodnego otaczającego niegdyś gród gdański oraz wał umocniony na koronie drewnem, 
który biegnąc wzdłuż tego brzegu mógł również pełnić funkcje komunikacyjne (Jażdżewski 1961, s. 36-37; Zbierski 1964, s. 75-79). Nieopodal, w rejonie ulic Podwale Staromiejskie, Igielnicka, Olejarna, Podzamcze, Katarzynki, Obornicka (stanowisko 2) natrafiono na sześć poziomów osadniczych z pozostałościami domów i warsztatów rzemieślniczych szewców, rogowiarzy i igielników (Hołowińska 1967, s. 186-187, 190; Barnycz-Gupieniec 1998, s. 7); najstarsze założenia datowano na początki XIII wieku. Poszukując architektury romańskiej, jeszcze w latach 50. i 60., wykonano badania sondażowe w kościele pw. św. Katarzyny i św. Mikołaja. W pierwszym, na głębokości około $4 \mathrm{~m}$ pod posadzką, natrafiono na obrabiane okrzeski i ślady wylewek, co zostało wówczas zinterpretowane jako relikty zniszczonego kościoła romańskiego i nigdy poważnie nie zaistniało w literaturze, w latach późniejszych odkryto tam pod prezbiterium wielowarstwowe cmentarzysko datowane na XIII wiek (Gładykowska-Rzeczycka 1998, s. 28-29). W kościele pw. św. Mikołaja natomiast zarejestrowano łęk ceglany zalegający pod obecną zakrystią, co niesłusznie uznano za najstarsze pozostałości tej świątyni, a pod kaplicą św. Jacka odkryto zwęglone konstrukcje drewniane, uznane za resztki wału(?) wczesnośredniowiecznego (Zbierski 1958, s. 60-63; 1978c, s. 248; 2003, s. 406-410). Po blisko 50 latach podjęto w tym rejonie, zarówno na placu pomiędzy kościołem św. Mikołaja a ulicą Szeroką, jak i pod samą świątynią, nowe badania, prowadzone od roku 2001 przez Andrzeja Gołembnika. W krypcie pod kapitularzem natrafiono na ślady wczesnośredniowiecznego osadnictwa oraz pozostałości cieku wodnego (Maciakowska 2001, s. 16-18; Gołembnik 2002, s. 17; 2009, s. 301-302; Trzeciecka, Trzeciecki 2002, s. 99-118). Pomiędzy ulicami Szeroką a Świętojańską zarejestrowano obiekty z materiałem ceramicznym datowanym na 2. połowę X wieku lub przełom X i XI wieku, których kontekst został zniszczony przez niwelację wykonaną tu $\mathrm{W}$ XI wieku. W następnym stuleciu teren ten był intensywnie użytkowany, być może jako plac targowy, po czym w XIV wieku nastąpiła jego kolejna niwelacja, zapewne związana z przyłączeniem do dominium Głównego Miasta (Trzeciecka, Trzeciecki 2002, s. 99-134).

Do badań Zofii Hołowińskiej na stanowisku 2 w rejonie ulicy Podwale Staromiejskie nawiązały ratownicze prace wykopaliskowe przeprowadzone przez H. Panera w latach 1989-1981 przy ulicy Podwale Staromiejskie $82^{7}$. W pobliżu dawnej ulicy Oborniki, w wykopie budowlanym o powierzchni $200 \mathrm{~m}^{2}$, natrafiono na relikty 28 domostw, zalegające w dziewięciu poziomach zabudowy (Paner 1993, s. 53-56; 1998, s. 184-205) ${ }^{8}$. Najstarsze z nich datowano metodą dendrochronologiczną od około 1151 do 1170 roku. Pozostałe konstrukcje występujące w wyższych poziomach zostały wykonane z drewna ściętego w latach 1190 i 1191 , w okresie od maja do lipca 1202 roku oraz w latach 1210 i 1225. Szereg konstrukcji

\footnotetext{
7 Badania prowadzone przez Henryka Panera i Zbigniewa Borcowskiego w 1991 roku przy współudziale Elżbiety Kołosowskiej i Bogdana Kościńskiego finansował znany gdański piekarz - Grzegorz Pellowski.

${ }^{8}$ Niestety, znaczna część domostw uległa zniszczeniu w trakcie wcześniejszych prac ziemnych.
} 
z kolejnych poziomów datowano na wiek XIV oraz początki XV. Za calec uznano strop zapiaszczonego torfu, który zalegał na poziomie od $0,003 \mathrm{~m}$ n.p.m. do $0,38 \mathrm{~m}$ n.p.m. Pierwsze konstrukcje drewniane występowały właśnie na stropie tego torfu. Towarzyszyły im warstwy trzciny i faszyny oraz mierzwa. Regularny układ domostw na osi północ - południe w północnej części wykopu budowlanego był nieco zakłócony. Odsłonięto tam konstrukcje mieszkalne w południowych częściach odchylone na zachód, w północnych zaś na wschód o 10-12 (sondaże 10-12). Układ ten powtarzał się w kolejnych poziomach późnośredniowiecznych usytuowanych na wysokości 2,2-2,3 m n.p.m. W kilku wykopach warstwy późnośredniowieczne były oddzielone od wczesnośredniowiecznych spalenizną grubości około $10 \mathrm{~cm}$ (sondaże 4, 5, 9). Odkryte domostwa w większości wzniesiono w technice zrębowej, dwa w sumikowo-łątkowej (w sondażu 8) oraz kilka w plecionkowej (w sondażach 1, 8, 9). Warto przypomnieć, że na stanowisku 1 , w poziomie ósmym, datowanym na lata 1140-1160, odkryto chatę wykonaną w konstrukcji sumikowo-łątkowej. Podłogi w większości budynków wykonane były z nawozu zmieszanego z gliną i piaskiem oraz pokryte płatami kory lub rzadziej dranic o grubości od 4,5 do $8 \mathrm{~cm}$. Paleniska odkryte wewnątrz domostw skonstruowano z zielonkawego iłu uformowanego w okrąg, który niekiedy był dodatkowo wzmocniony drewnianymi ramami mocowanymi po bokach palikami. $\mathrm{W}$ jednym z domów odkryto pozostałości pieca kopułowego zbudowanego na starszym palenisku otwartym. W poziomach od drugiego do szóstego, datowanych na okres od połowy XII do XIII wieku, natrafiono na ślady intensywnej produkcji rogowiarskiej, zaś w poziomach od pierwszego do czwartego, z połowy XII do przełomu XII i XIII wieku - garbarskiej i szewskiej. Wewnątrz domostw znaleziono pierścionki, kabłączki, fragmenty bransolet, grudki bursztynu i półwytwory bursztynowe oraz noże. W pomieszczeniach wykorzystywanych przez rogowiarzy znaleziono grzebienie z poroża datowane w oparciu o przyjęte klasyfikacje na 2. połowę XIII i XIV wiek (Hilczer-Kurnatowska 1961, s. 41-144), a także duże ilości surowca, półfabrykatów i odpadów produkcyjnych. W poziomach wczesnośredniowiecznych (od 1 do 6) występowały głównie naczynia ceramiczne o esowatym profilu oraz pojedynczo czarki, naczynia flaszowate i z cylindryczną szyjką. W poziomie 6 , datowanym na wiek XIII natrafiono też na fragmenty naczyń importowanych barwy zielono-oliwkowej z charakterystycznym plastycznym ornamentem w postaci łusek. Część starszej zabudowy zniszczyły urządzenia sanitarne (latryny) z XV i XVI wieku, z których wydobyto całe naczynia, dobrze zachowane fragmenty obuwia oraz kopyta szewskie.

W latach 90. XX wieku B. Kościński przeprowadził badania ratownicze u zbiegu ulic Podwale Staromiejskie 69 i Sołeckiej; łącznie objęły one obszar $260 \mathrm{~m}^{2}$. Najstarsze ślady działalności człowieka odsłonięto tu na poziomie 0,2 m n.p.m. Wydzielono siedem poziomów wczesnośredniowiecznych, drewnianych konstrukcji sumikowo-łątkowych i zrębowych o miąższości około $2 \mathrm{~m}$, 
które stanowiły pozostałości po regularnej zabudowie mieszkalnej i gospodarczej tej części miasta, datowanej roboczo na XIII wiek. Zabudowa ta koncentrowała się wzdłuż drogi o konstrukcji legarowej, biegnącej z północnego wschodu na południowy zachód, prawdopodobnie od miasta do grodu. Wspomniana droga występowała przez wszystkie fazy wczesnośredniowiecznej zabudowy, podobnie jak leżące obok niej budynki z warsztatem rogowiarskim. W posesjach nr 70 i 71 odsłonięto ceglane paleniska i ułożone z cegieł posadzki, zapewne pozostałości po zabudowie szkieletowej datowanej na schyłek późnego średniowiecza. Do tych obiektów, zdaniem B. Kościńskiego ${ }^{9}$, nawiązywały latryny odkryte pod podłogami murowanych domów z XVI wieku, gdzie natrafiono na bogatą kolekcję naczyń z 1. połowy XV wieku (Kościński 1998, s. 94-118). Głęboko wkopane kamienne fundamenty murowanych domostw zniszczyły pozostałości starszych konstrukcji szkieletowych. Poza naczyniami na uwagę zasługują inne znaleziska: pierścionki i kabłączki datowane na wczesne średniowiecze, wczesnośredniowieczne brakteaty oraz kolekcja produktów i półproduktów, surowca i odpadów rogowiarskich, a także naczyń drewnianych i obuwia.

Interesujące wyniki przyniosły też badania prowadzone w obrębie Wielkiego Młyna, w swej obecnej formie datowanego na XIV wiek ${ }^{10}$, usytuowanego na wysepce zwanej Tarczą (Schild), położnej w widłach nowego kanału młyńskiego, tuż poniżej Mostu Ław Chlebowych ${ }^{11}$. Za młynem odkryto trzy poziomy drewnianych ulic i pozostałości domów, datowane na lata 1230, 1261 i 1301. W trakcie badań wykopaliskowych, wewnątrz Wielkiego Młyna, pod fundamentami ceglanymi i kamiennymi podtrzymującymi niegdyś urządzenia młyńskie, natrafiono na palenisko z XI wieku i studnię z XIII wieku, fragmenty wczesnośredniowiecznych naczyń ceramicznych, a także konstrukcje drewniane o niewyjaśnionym dotąd przeznaczeniu, datowane metodą dendrochronologiczną na około 1350 rok. Ponieważ jeszcze w początkach XIV wieku gdańszczanie korzystali z młyna w św. Wojciechu, wielu badaczy uważa, że wcześniej nie funkcjonował w Gdańsku żaden młyn zbożowy. Wielki Młyn o wysokości $26 \mathrm{~m}$ i długości $41 \mathrm{~m}$ był w średniowieczu największym zakładem przemysłowym Gdańska i posiadał początkowo 12, później 18 kół o średnicy około $5 \mathrm{~m}$. Jego poddasze liczące sześć kondygnacji służyło do przechowywania zapasów zboża i mąki, a przerób sięgał 3,5 do 4 tysięcy łasztów ziarna rocznie, co daje dziennie około $43 \mathrm{~m}^{3}$, jeśli założyć pracę we wszystkie dni tygodnia z wyjątkiem niedziel. Pierwsza ordynacja Wielkiego Młyna pochodzi z 1365 roku, jednak wiadomo, że

\footnotetext{
9 Opinia złożona w Archiwum Muzeum Archeologicznego w Gdańsku, dotycząca badań ratowniczych na stanowisku przy ulicy Podwale Staromiejskie 69 w Gdańsku.

${ }_{10}$ Badania prowadzili Marian Kochanowski, Mirosław Fudziński i Olgierd Felczak.

${ }^{11}$ Budowa kanału Raduni, wspomnianego po raz pierwszy w źródłach w 1338 roku, była związana z potrzebami gospodarki krzyżackiej, tj. uruchomieniem młyna zbożowego usytuowanego pomiędzy św. Wojciechem a Pruszczem Gdańskim oraz dostarczeniem wody pitnej do zamku krzyżackiego w Gdańsku i do miasta.
} 
jeszcze przed rokiem 1338 z okolic Pruszcza Gdańskiego wykopano, przez Stare Miasto, uchodzący do Wisły sztuczny kanał, młyński. Jednym z jego zadań było zasilanie fosy zamkowej. Jednak przed rokiem 1356 Krzyżacy przekopali nowy kanał młyński, który biegnąc od Orunii, przejmował po drodze wody Potoku Siedleckiego. Opinie na temat jego przebiegu są podzielone. Jedni badacze uważają, że na obszarze Starego Miasta puszczono go korytem starego kanału ${ }^{12}$, prowadząc od niego kilka mniejszych kanałów zasilających nowo powstałe wówczas urządzenia przemysłowe, inni opowiadają się raczej za istnieniem dwóch kanałów: starego i nowego, przy czym ten pierwszy miałby uchodzić do Motławy na południe od kościoła św. Katarzyny, drugi zaś wpadać do Wisły na północ od tego kościoła ${ }^{13}$. Wielki Młyn uległ spaleniu w 1391 roku, został jednak szybko odbudowany, do czego znacznie przyczyniły się opłaty specjalne wymuszone przez Krzyżaków na usługobiorcach. Okolice Wielkiego Młyna wiążą się ściśle z hipotezą dotyczącą lokalizacji na Starym Mieście XIII-wiecznego miasta na prawie lubeckim. Zwolennikami umiejscowienia go właśnie tutaj są między innymi Kazimierz Jasiński (1978, s. 271-297) i Józef Spors (1982, s. 17-81). Na Głównym Mieście chcieli je widzieć Walther Stephan (1911, s. 3-9), Erich Keyser (1913, s. 149 i nn.) i A. Zbierski (1978b, s. 194-223). W pobliżu Wielkiego Młyna, w miejscu obecnej piekarni Grzegorza Pellowskiego, również odkryto pozostałości wczesnośredniowiecznej zabudowy (półziemianka), wstępnie datowane na XI-XII wiek $^{14}$.

W latach 1999-2000 w rejonie ulic Rajskiej i Heweliusza natrafiono na wczesnośredniowieczną osadę (XII-XIII wiek), zniszczoną przez pożar. Zrejestrowano tam półziemianki, jamy śmietniskowe i paleniska osady rybackiej, a także umocniony faszyną i palowaniem brzeg cieku wodnego. Na przełomie XIII i XIV wieku nastąpiła tutaj intencjonalna rozbiórka budynków zniszczonych przez pożar, między innymi szkieletowego (nr 2818), wzniesionego na planie kwadratu o boku $6,50 \mathrm{~m}, \mathrm{z}$ dużym aneksem o długości ponad $9 \mathrm{~m}$. Dom spłonął u schyłku XIII bądź na początku XIV wieku, kiedy to zniszczeniu uległo całe osadnictwo w tym rejonie. Rozebrano wówczas ściany budynków, słupy konstrukcji nośnych ścięto na poziomie podłóg, a pozostałe po rozbiórce zagłębienia wypełniono gliną (Szyszka, Krzywdziński 2003, s. 137-141; Paner 2006, s. 36-37). Podobne zjawisko zaobserwowano pomiędzy ulicami Elżbietańską, Karmelicką i Podwalem Grodzkim, gdzie odkryto ziemianki, jamy gospodarcze i paleniska z importowaną ceramiką skandynawską, datowane na XII i XIII wiek. Na całym tym obszarze

${ }^{12}$ Dla tego kanału badacze rezerwują nazwę Kanał Raduni lub Kanał Młyński.

${ }^{13} \mathrm{~W}$ dokumencie z 1356 roku znajdujemy wzmiankę o dwóch kanałach młyńskich, tj. novum fossatum molendini i antiquum fossatum molenini, jednak zapewne chodzi tu o ich przebieg na terenie dzielnicy Orunia i Stare Szkoty.

${ }^{14}$ Badania prowadził H. Paner. Po ich zakończeniu wewnątrz Wielkiego Młyna urządzono na koszt inwestora ekspozycję części reliktów najstarszego budynku młyna, wzbogaconą o animację komputerową. 
została przeprowadzona planowa niwelacja na początku XIV wieku (Paner 2006, s. 32; Borcowski 2009, s. 89-104).

W ostatnich dekadach najciekawsze wyniki przyniosły badania prowadzone na Placu Dominikańskim oraz pod budynkiem Hali Targowej. Poszukiwanie najstarszych reliktów kościoła św. Mikołaja i klasztoru dominikanów w Gdańsku miało miejsce już w latach 50. XX wieku, fundamenty wspomnianego kościoła zostały wówczas błędnie datowane na XII wiek (Zbierski 1958, s. 53-77). Jednakże podczas najnowszych badań prowadzonych przez Muzeum Archeologiczne w Gdańsku odkryto pod Halą Targową kamienne fundamenty dwóch romańskich kościołów: starszego, datowanego na około 1190 rok oraz młodszego, przebudowanego właśnie przez zakon dominikanów po roku 1227 (Borcowski 2009, s. 93-102; Paner 2009, s. 35-36; Szyszka 2009a, s. 105-136). Ponadto odkryto też wielowarstwowe cmentarzysko oraz pozostałości wczesnośredniowiecznej osady.

Osada powstała tutaj już w X wieku, najpierw z obiektami mieszkalnymi w postaci półziemianek (Borcowski 2009, s. 92), następnie wzbogacona o mieszkalno-gospodarcze zbudowania wzniesione w konstrukcji zrębowej i sumikowo-łątkowej, znacznie rzadziej słupowej i plecionkowej. W 2. połowie $\mathrm{X}$ wieku w zachodniej części Kępy Dominikańskiej powstał cmentarz, na którym zmarłych ułożono w grobach głowami na zachód. Znaczna część pochówków znajdowała się w owalnych jamach, choć w wielu grobach natrafiono też na resztki trumien (Krzywdziński 2007, s. 7-64; 2010, s. 9-56). U schyłku XII wieku na obszarze cmentarza wzniesiono pierwszy kościół, którego fundamenty przecięły kilkanaście najstarszych jam grobowych. W tym samym czasie nadal funkcjonowała osada i rozrastający się na wschód od apsydy cmentarz. Ten starszy kościół był orientowaną świątynią jednonawową z trójdzielnym masywem zachodnim i prezbiterium $\mathrm{w}$ formie półkolistej apsydy o wewnętrznym promieniu $4 \mathrm{~m}$, przechodzącej w prostokątne prezbiterium o długości $4,8 \mathrm{~m}$ i szerokości wewnętrznej $7,8 \mathrm{~m}$. Prezbiterium od zachodu zostało zamknięte podporami pod łuk tęczowy. Długość całego założenia wynosiła $34,5 \mathrm{~m}$, zewnętrzna długość fundamentów nawy 17,4m, szerokość 14,6m. Od zachodu nawa była zamknięta murem poprzecznym, na którym wzniesiono filary wspierające masyw zachodni o szerokości $17,3 \mathrm{~m}$ i długości $6,9 \mathrm{~m}$. Masyw ten był murowany z cegły o wymiarach 90-105×120-135×275-285 mm, ułożonej w wątku wendyjskim. Zamykały go dwie wieże o wymiarach $6,9 \times 6,9 \mathrm{~m}$ każda, pomiędzy nimi centralnie usytuowano wejście do świątyni, obramione portalem. Nad kruchtą znajdowała się empora, zapewne otwarta na nawę arkada o rozpiętości około 3,5m. Kościół ten został zniszczony przez pożar w latach 20 . XIII wieku, prawdopodobnie w trakcie najazdu Prusów (Szyszka 2003, s. 485-499; Paner 2009, s. 35-36; Szyszka 2009a, s. 105-136; 2009b, s. 621-622).

Młodszy kościół powstał na tych samych fundamentach i został przebudowany przez dominikanów zgodnie z ówczesnymi zasadami dotyczącymi kościołów 
zakonów żebraczych. Rozbudowano o 10m wschodnią część, przy jednoczesnym skróceniu o około $5 \mathrm{~m}$ zachodniej części, a nowe założenie osiągnęło długość $40 \mathrm{~m}$. Na miejscu rozebranej apsydy wybudowano prostokątny chór o wewnętrznej długości $11 \mathrm{~m}$ i szerokości $7 \mathrm{~m}$, przykryty zapewne dwoma polami sklepień krzyżowych. Długość nawy po przebudowie wynosiła około $27 \mathrm{~m}$, szerokość zaś 13,5 m; miała zapewne płaski, drewniany strop. Przejście pomiędzy nawą a prezbiterium podkreślono dwoma symetrycznie rozmieszczonymi aneksami o wymiarach 9,5 ×5,5 m każdy. Prawdopodobnie pełniły one rolę kaplic bocznych lub ramion transeptu (Szyszka 2009b, s. 627-628; Paner 2009, s. 35).

Na podstawie wyników badań w piwnicach Hali Targowej ustalono, też że w roku 1308 kościół i najstarsze zabudowania klasztorne zostały zniszczone przez zakon krzyżacki. Następnie w 1. połowie XIV wieku zbudowano na nowym miejscu gotycki kościół pw. św. Mikołaja i przylegające do niego od północy zabudowania klasztoru (Borcowski 2009, s. 89-104). Działania te poprzedziło zbudowanie na ówczesnym placu klasztornym, kilka metrów na wschód od najstarszego kościoła Dominikanów, dużego, ceglanego pieca wapienniczego o wymiarach $460 \times 610 \mathrm{~cm}$. Piec ten, o kubaturze około $40 \mathrm{~m}^{3}$, pozwalał uzyskać z jednorazowego wypału około 70 ton wapna (Borcowski 2009, s. 101).

W trakcie badań prowadzonych na terenie obecnego Placu Dominikańskiego, który leży pomiędzy obecnym kościołem pw. św. Mikołaja a Halą Targową, natrafiono na najstarsze zachowane pozostałości klasztoru Dominikanów, datowane w świetle najnowszych badań na 2. połowę XIII wieku (Kajzer 2003, s. 423-436; Szyszka 2009b, s. 610-640; Świechowski 2009, s. 71-73). Był to podpiwniczony budynek zniszczony w czasie najazdu Krzyżaków na Gdańsk w roku 1308 (Szyszka 2009b, s. 630-632). Zachowała się jedynie podziemna kondygnacja o powierzchni około $52 \mathrm{~m}^{2}$ i wysokości 3,2m. Pomieszczenie nakrywało czteropolowe sklepienie, oddzielone gurtami, oparte na centralnym filarze i pendentywach. Pierwotnie kondygnacja ta była zagłębiona około $1,4 \mathrm{~m}$ w ziemię. Konstrukcja ścian i sklepienia opierała się na ośmiu filarach przyściennych i wspomnianym już filarze centralnym (Szyszka 2009b, s. 632). W zachodniej części południowej ściany znajdowało się wejście do piwnicy, natomiast we wschodniej części ściany północnej glifione okno dla wentylacji pomieszczenia. Pomimo licznych przebudów, zarówno w średniowieczu, jak i w czasach nowożytnych zachowały się fragmenty oryginalnych sklepień, detal architektoniczny: „uskokowo kształtowane filary przyścienne, filar centralny, blendy o wykroju pełnego i ostrego łuku, konsole (wsporniki), ostrołukowe wysklepione gurty, glifione okno wentylacyjne, podstawa pieca, detal kamieniarski” (Szyszka 2009b, s. 633). W 2009 roku rozpoczęto $\mathrm{w}$ tym obiekcie prace konserwatorskie i adaptacyjne, które zostały uwieńczone w końcu 2014 roku, oddaniem obiektu do użytku zwiedzających, jako kolejny oddział Muzeum Archeologicznego w Gdańsku. 
Już w XXI wieku miały miejsce znaczące odkrycia w rejonie ulic Panieńskiej i Tartacznej, gdzie najstarsze warstwy datowano na około połowę XII wieku, natomiast budynki z poziomu późnośredniowiecznego zostały rozebrane pod koniec lat 40. XIV stulecia, kiedy przeprowadzono tutaj Kanał Młyński (Misiuk 2013, s. 337-370). Niemniej, przez blisko 200 lat istniało w tym miejscu stabilne osadnictwo.

\section{Główne Miasto}

Z wyjątkiem dobrze znanych w literaturze odkryć dokonanych przez A. Zbierskiego pod budynkiem ratusza Głównego Miasta (Zbierski 1978a, s. 71-125; 1978b, s. 194-223), nigdzie w pobliżu nie stwierdzono osadnictwa starszego niż ze schyłku XIII wieku. W 1995 roku pobrano próby drewna z konstrukcji odkrytych niegdyś przez wspomnianego badacza w wykopach przy ulicach Długiej i Kuśnierskiej. Zostały one wydatowane na 932 rok i, jak na razie, jest to najstarsza, pewna data roczna dla Gdańska. Daty uzyskane z pozostałych prób mieszczą się w 2. połowie XIII wieku (1251 rok, po 1267 roku, 1269 rok $^{15}, 1300$ rok $^{16}$ ) oraz na 1. połowę XIV wieku (1331 rok, 1334 rok, 1335 rok, 1340 rok $^{17}$ ). Nie wiemy jednak z jakich konstrukcji pobrano próbki, ponieważ wykopy przez kilka lat były zalane wodą, na skutek czego drewniane elementy uległy wypłukaniu i przemieszczeniu.

W latach 1995 i 1996, korzystając z remontu piwnic, przeprowadzono badania sondażowe w rejonie północnej krawędzi ulicy Długi Targ, w piwnicach ówczesnego Jazz Clubu ${ }^{18}$. Jak dotąd, udało się datować tylko jedną z prób drewna na rok $1300^{19}$, niżej jednak zalegały starsze warstwy, których dokładna chronologia nie została ustalona.

Brak osadnictwa z wczesnego średniowiecza stwierdzono między innymi przy ulicy Piwnej (obok Komendy Rejonowej Policji) ${ }^{20}$, przy ulicach Długi Targ i Powroźniczej (gdzie przebadano $1200 \mathrm{~m}^{2}$ ), przy ulicy Pocztowej, między ulicami św. Ducha a Mariacką, po wschodniej stronie Kaplicy Królewskiej $\left(932 \mathrm{~m}^{2}\right)$, przy ulicy Grząskiej $\left(360 \mathrm{~m}^{2}\right)$, czy przy ulicy Kleszej $\left(320 \mathrm{~m}^{2}\right)$. W 1992 roku Zbigniew Borcowski i Elżbieta Kołosowska przeprowadzili badania na zapleczu posesji przy ulicy Powroźników 3. Warstwy o charakterze niwelacyjno-izolacyjnym zalegające na calcu datowano w oparciu o materiał ceramiczny na XIV wiek oraz

15 Dwie ostatnie daty z błędem $+x$ (tj. nie więcej niż 20 lat) i -6 lat.

${ }^{16}$ Data obarczona błędem +8 i -6 lat

17 Wszystkie $z$ błędem $+x$ i -6 lat.

18 Badania prowadzili Henryk Paner i Olga Hutkowska.

19 Data pochodzi z deski nr 9.

${ }^{20}$ Odkryto tu konstrukcje drewniane datowane od roku 1306 do lat 1352, 1362 i 1370 oraz latryny z okresu nowożytnego. Nie natrafiono natomiast na ślady osadnictwa wczesnośredniowiecznego. 
przełom XV i XVI stulecia. W wyniku analizy dendrochronologicznej ustalono, że drewno użyte w konstrukcjach najstarszych znalezionych tu domostw zostało ścięte w latach od 1333-1334 do 1389. W zachodniej części wykopu natrafiono na beczkę bez dna o średnicy $1 \mathrm{~m}$, wkopaną w łatwo przesiąkalne warstwy calca, wiążącą się z najstarszymi poziomami piwnic. Jej funkcja nie jest całkiem jasna (drenaż?), bowiem jedyne wypełnisko stanowił gruz ceglany pochodzący z późniejszych destrukcji. W wyniku przeprowadzonych analiz specjalistycznych ustalono, że beczkę wykonano z drewna ściętego w zachodnich Niemczech w latach $1348-1358^{21}$.

\section{Miasto lubeckie}

Jedną z większych niewiadomych rozwoju przestrzennego Gdańska jest tzw. Miasto lubeckie - temat który od ponad 100 lat frapuje wszystkich badaczy zajmujących się dziejami tego miasta, przy czym dyskusja toczy się głównie odnośnie jego lokalizacji bądź to na Starym, bądź to na Głównym Mieście. Z całą pewnością już od lat 20. XIII wieku mogła istnieć w Gdańsku gmina kupców lubeckich, a około 1260 roku lokowano miasto na prawie lubeckim (Jasiński 1996, s. 57). Jak dotąd, nie posiadamy przekonywujących ewidencji archeologicznych, które mogłyby pomóc w dokładnym ustaleniu granic i kształtu tej części miasta. Ponadto dopiero początek XV wieku to czas, w którym dobiega końca kształtowanie się średniowiecznego zespołu urbanistycznego Gdańska, gdzie zarazem pewnemu ,zamazaniu” ulegają niektóre starsze organizmy przestrzenne, wcześniej funkcjonujące na tym terenie. Proces ten możemy obserwować głównie dzięki wynikom badań archeologicznych, jako że aż do połowy XIV wieku dysponujemy bardzo ograniczoną liczbą źródeł pisanych, w szczególności jeśli chodzi o obszar Głównego Miasta (Maciakowska 2011). Jeszcze do początku poprzedniego stulecia większość badaczy uważała, że Główne Miasto zostało założone na tzw. surowym korzeniu. Z tej utartej w nauce opinii wyłamali się W. Stephan publikując pracę pt. „Die Strassennahmen Danzigs” (1911) oraz E. Keyser, który postawił tezę o lokowaniu miasta na prawie lubeckim przez księcia Świętopełka na obszarze późniejszego Głównego Miasta. Przeciwnikiem teorii W. Stephena był Paul Simson, dając temu wyraz w historii Gdańska opublikowanej w 1913 roku. W latach powojennych do teorii W. Stephena i E. Keysera nawiązał A. Zbierski, opierając się na odkryciu domów mieszkalnych znalezionych pod ratuszem Głównego Miasta i datowanych przez niego na XIII wiek (Zbierski 1975, s. 55-66). Jednakże wyniki badań wykopaliskowych prowadzonych przez ostatnie lata na terenie Głównego Miasta, w tym także w najbliższej okolicy ratusza, nie pozwalają na utrzymanie tej tezy (Paner 2004a, s. 15-32; 2004b, s. 65-73).

${ }^{21}$ Analizy wykonał Tomasz Ważny w Pracowni Dendrochronologicznej ASP w Warszawie. 
Dokonując podsumowania badań za ostatnie 30 lat, nie znalazłem dostatecznych podstaw dla potwierdzenia lokalizacji miasta lubeckiego na tym obszarze. W żadnym z wykopów nie znaleziono śladów osadnictwa starszego niż ze schyłku XIII wieku bądź 1. połowy XIV wieku. Natomiast odkrycia dokonane na terenie Starego Miasta zdecydowanie potwierdzają osadnictwo istniejące tu już od $\mathrm{X}$ wieku, co pozwala dopatrywać się właśnie w tym rejonie także i miasta lubeckiego. W mojej opinii mogło się ono znajdować na terenach położonych na północ od kościoła pw. św. Mikołaja, być może nawet po rejon ulicy Gnilnej, od wschodu po szpital św. Ducha i ulicy Olejarnia, od zachodu do ulicy Podwale Grodzkie i wreszcie od południa nie przekraczając linii ulicy Podwale Staromiejskie. Zdaniem Zofii Maciakowskiej bardziej prawdopodobny dla lokalizacji miasta lubeckiego jest obszar od południowo-zachodnich granic Targu Drzewnego aż po kościół pw. św. Katarzyny, przy czym - zdaniem badaczki - nie można bliżej określić zasięgu północnego, choć należy brać pod uwagę że przypuszczalnie obejmowało ono obszar, na którym postawiono później Wielki Młyn. Jak się wydaje kwestia dokładniejszej lokalizacji miasta lubeckiego w Gdańsku może zostać wyjaśniona jedynie poprzez dalsze badania archeologiczne, szczególnie w rejonie ulic Kowalskiej, Garncarskiej i na Piaskach, gdzie - jak dotąd - prowadzono tylko nieliczne prace.

Reasumując, Gdańsk doskonale wpisuje się w twierdzenie, że wczesne miasta środkowej części Europy są zespołami osadniczymi złożonymi z elementów zróżnicowanych pod względem formy i pełnionych funkcji, przy czym cechuje je wieloczłonowość i nieregularność układów przestrzennych (Rębkowski 2001, s. 25-27). Tak właśnie jawi nam się wczesnośredniowieczny Gdańsk w świetle dotychczasowych wyników badań archeologicznych. Wyniki te posłużyły nie tylko do rozlicznych opracowań naukowych, ale również zostały udostępnione zwiedzającym w formie nowoczesnej ekspozycji. Powstała ona w 2008 roku w budynku oryginalnego gdańskiego spichrza i prezentuje między innymi zrekonstruowany fragment średniowiecznego miasta z XIII-XIV wieku w postaci uliczki wypełnionej domostwami oraz warsztatami i sklepami. Uliczka ta jest wzbogacona rekonstrukcjami postaci średniowiecznych gdańszczan, wykonanych w oparciu o materiał szkieletowy pozyskany w trakcie badań pod Halą Targową oraz wzbogacona hałasami i zapachami średniowiecznego miasta. Spichlerz o nazwie „Błękitny Baranek”, w którym prezentowana jest wystawa, położony przy ulicy Chmielnej 53, otrzymał w 2011 roku prestiżową nagrodę Unii Europejskiej „Europa Nostra” za rekonstrukcję i adaptację obiektu zabytkowego na cele muzealne. 
Literatura

Wykaz skrótów

Archeologia - Archeologia Gdańska, t. 1, red. H. Paner, Gdańsk

Gdańsk

- Gdańsk wczesnośredniowieczny, red. J. Kamińska, Wrocław, Gdańsk

Gdańsk średniowieczny - Gdańsk średniowieczny w świetle najnowszych badań archeologicznych i historycznych, red. H. Paner, J. Iluk, Gdańsk

Historia - Historia Gdańska, t. 1 (do roku 1454), red. E. Cieślak, Gdańsk

SW - Studia Wczesnośredniowieczne. Studia, Materiały, Sprawozdania, Warszawa-Wrocław

Archaeologia urbium

1966 Archaeologia urbium: corpus des ensembles archeologiques, des villes du haut Moyen Age, fasc. 1: Pl. 1-30: Le Gdańsk des X-XIII siècles, red. W. Hensel, Warszawa.

Barański M.

1994 Załogi grodowe w Polsce wczesnopiastowskiej, [w:] Społeczeństwo Polski średniowiecznej, t. 6, red. S. K. Kuczyński, Warszawa, s. 91-100.

Barnycz-Gupieniec R.

1961 Tokarstwo i bednarstwo z XIII-XIV wieku w osadzie miejskiej w Gdańsku, Materiały Zachodniopomorskie, t. 7, s. 391-434.

1974 Drewniane budownictwo mieszkalne w Gdańsku w X-XIII wieku, WrocławGdańsk.

1998 Badania nad wczesnośredniowiecznym Gdańskiem. Historia - rezultaty, [w:] Gdańsk średniowieczny, s. 5-11.

2003 Analiza planigraficzna materiatu zabytkowego grodu gdańskiego z X-XII wieku (stanowisko 1), [w:] XIII Sesja Pomorzoznawcza, t. 2: Od wczesnego średniowiecza do czasów nowożytnych, red. H. Paner, M. Fudziński, Gdańsk, s. $11-18$.

Borcowski Z.

2009 Stanowisko 5 w ujęciu funkcjonalno-chronologicznym, [w:] Archeologia, t. 1, s. $89-104$.

Byrska E.

1955 Budownictwo $w$ gdańskiej dzielnicy rybackiej $w$ XII $i$ XIII w., SW, nr 3, s. $217-232$.

Chmielowska A.

1960 Wyroby szklarskie z X-XIII wieku na stanowisku 1 w Gdańsku, [w:] Gdańsk, t. 3, s. $105-157$.

Dąbrowski F.

2007 Studia nad administracją kasztelańska Polski XIII wieku, Warszawa. 
Gładykowska-Rzeczycka J. J.

1998 Antropologiczne badania materiałów kostnych ze średniowiecznych obiektów Pomorza Gdańskiego, [w:] Gdańsk średniowieczny, s. 26-42.

Gołembnik A.

2002 Zachodnia pierzeja ulicy Szklary-problematyka badawcza, [w:] Dominikańskie Centrum św. Jacka w Gdańsku. Badania archeologiczne, t. 2, red. A. Gołembnik, Warszawa, s. 7-17.

2009 Wyniki prac wykopaliskowych w kościele św. Mikołaja i ich wartość dla poznania topografii najstarszych poziomów osadniczych Gdańska, [w:] Stan badań archeologicznych miast $w$ Polsce, red. H. Paner, M. Fudziński, Z. Borcowski, Gdańsk, s. 295-308.

Gołębiewski A.

2005a Zamczysko $w$ Gdańsku - nowe fakty i ustalenia $w$ świetle badań archeologicznych 2002-2003, [w:] XIV Sesja Pomorzoznawcza, t. 2: Od wczesnego średniowiecza do czasów nowożytnych, red. H. Paner, M. Fudziński, Gdańsk, s. 49-65.

2005b Zamczysko w Gdańsku. Historia $i$ wyniki nowych badań archeologicznych, Pomorania Antiqua, t. 20, s. 327-385.

Gupieniec A.

1963 Monety średniowieczne znalezione na terenie Gdańska, Prace i Materiały Muzeum Archeologicznego i Etnograficznego w Łodzi, seria archeologiczna, nr 9, s. 167-193.

Hilczer-Kurnatowska Z.

1961 Rogownictwo gdańskie w X-XIV wieku, [w:] Gdańsk, t. 4, s. 41-144.

Hołowińska Z.

1959 Wczesnośredniowieczne rzemiosło złotnicze w Gdańsku, [w:] Gdańsk, t. 1, s. 55-105.

1960 Materiaty archeologiczne do badań nad najstarszym Gdańskiem lokacyjnym, Kwartalnik Historii Kultury Materialnej, R. 8, nr 1, s. 183-239.

1967 Dzielnica rzemieślnicza z XIII-XIV wieku w Gdańsku (stanowisko 2), [w:] Gdańsk, t. 6, s. 183-243.

Jasiński K.

1978 Gdańsk w okresie samodzielności politycznej Pomorza Gdańskiego, [w:] Historia, s. 271-297.

1996 Początki gminy miejskiej w Gdańsku. Na marginesie badań nad dokumentem Świętopełka dla dominikanów gdańskich z 1227 r., [w:] Studia nad dziejami miast i mieszczaństwa $w$ średniowieczu. Studia ofiarowane Profesorowi Antoniemu Czacharowskiemu w sześćdziesiąta piąta rocznicę urodzin i czterdziestolecie pracy naukowej, Studia Polonica Historiae Urbanae, t. 2, red. R. Czaja, J. Tandecki, Toruń, s. 43-57.

Jaworski Z.

1952 Szczątki zwierząt ssących i ptaków z grodu gdańskiego z XIII w., SW, nr 1, s. $85-91$. 
1958 Gdańsk X-XIII w. na tle Pomorza wczesnośredniowiecznego, [w:] Pomorze średniowieczne, red. G. Labuda, Warszawa, s. 73-120.

1961 Gdańsk wczesnośredniowieczny w świetle wykopalisk, Gdynia.

Kajzer L.

2003 Stolica bez romańszczyzny?, [w:] Dominikanie. Gdańsk-Polska-Europa, red. D. A. Dekański, A. Gołembnik, M. Grubka, Gdańsk-Pelplin, s. 423-436.

Kamińska J.

1955 Gdańsk wczesnośredniowieczny w świetle siedmiu lat archeologicznych prac badawczych, Gdańsk.

Kamińska J., Nahlik A.

1958 Włókiennictwo gdańskie w X-XIII wieku, Łódź.

Keyser E.

1921 Die Besiedlung der Altstadt Danzig, Zeitschrift des Westpreussischen Geschichtsvereins, t. 61, s. 149-192.

Kmieciński J.

1955a Umocnienia grodu gdańskiego we wczesnym średniowieczu, SW, nr 3, s. 233-237.

1955b Sprzęt rybacki i organizacja rybołówstwa w Gdańsku w XII i XIII w. w świetle prac wykopaliskowych w 1. 1948-1951, SW, nr 3, s. 212-216.

Kościński B.

1998 Wstępne wyniki badań na stanowisku 2 w Gdańsku w 1996 roku, [w:] Gdańsk średniowieczny, s. 94-118.

Kościński B., Paner H.

2005 Nowe wyniki datowania grodu gdańskiego - stanowisko 1 (wyk. I-V), [w:] XIV Sesja Pomorzoznawcza, t. 2: Od wczesnego średniowiecza do czasów nowożytnych, red. H. Paner, M. Fudziński, Gdańsk, s. 9-47.

Krysiak K.

1956 Wyniki badań nad materiałem zwierzęcym z wykopalisk w Gdańsku, Wrocław.

1967 Szczątki zwierzęce z wykopalisk w Gdańsku, [w:] Gdańsk, t. 6, s. 7-51.

Krzywdziński R.

2007 Cmentarzysko ze stanowiska 5-Hala Targowa w Gdańsku od połowy XII wieku do 1813 roku, [w:] Archeologia, t. 2, s. 7-64.

2010 Cmentarzysko na Placu Dominikańskim w Gdańsku (badania z 2002 i 2003 roku), [w:] Archeologia, t. 4, s. 9-56.

Kubasiewicz M.

1977 Badania archeozoologiczne na terenie Gdańska IX-XIV wieku, [w:] Gdańsk, t. 9.

Kunicka-Okuliczowa Ł.

1959 Wczesnośredniowieczne zabawki i gry z Gdańska, [w:] Gdańsk, t. 1, s. 107143.

Lechnicki F.

1955 Szczątki roślinne z wykopalisk gdańskich w latach 1950-1952, SW, nr 3, s. $252-259$. 
Lechnicki F., Klichowska M., Gupieniec R.

1961 Szczątki roślinne ze stanowiska 1 w Gdańsku (wykop główny), [w:] Gdańsk, t. 4, s. 5-25.

Lepówna B.

1967 Próba synchronizacji stanowisk archeologicznych na terenie Gdańska w oparciu o materiat ceramiczny, [w:] Gdańsk, t. 6, s. 101-136.

1968 Garncarstwo gdańskie w X-XIII wieku, [w:] Gdańsk, t. 7.

Łosiński W.

2001 Początki wczesnośredniowiecznego Gdańska. Problem widziany z oddalenia, Slavia Antiqua, t. 42, s. 51-59.

Maciakowska Z.

2011 Kształtowanie przestrzeni miejskiej Głównego Miasta w Gdańsku do poczatku XV wieku, [w:] Fontes commentationesque ad res gestas Gedani et Pomeraniae, t. 3, red. H. Paner, Gdańsk.

Mądalski J.

1952 Szczątki roślinne z wykopalisk w Gdańsku, SW, nr 1, s. 97-98.

Misiuk Z.

2013 Wstepne wyniki badań archeologicznych prowadzonych na obszarze protomiasta gdańskiego pomiędzy dzisiejszymi ulicami Tartaczna i Panieńska w Gdańsku w latach 2008-2010, [w:] XVII Sesja Pomorzoznawcza, t. 2: Od późnego średniowiecza do czasów nowożytnych, red. H. Paner, M. Fudziński, Gdańsk, s. 337-370.

Moździoch S.

2002 Castrum munitissimum Bytom. Lokalny ośrodek władzy w państwie wczesnopiastowskim, Warszawa.

Paner H.

1993 Badania ratownicze na Starym Mieście w Gdańsku w 1990 roku. Gdańsk stanowisko 2, Sprawozdania Gdańskiego Towarzystwa Naukowego, nr 18, s. 53-56.

1998 Problematyka badań nad średniowiecznym Gdańskiem w świetle prac archeologicznych prowadzonych w latach 1987-1997, [w:] W świetle najnowszych badań archeologicznych i historycznych, red. H. Paner, J. Iluk, Gdańsk, s. 184-205.

2004a The spatial development of Gdańsk to the beginning of the 14th century. The origins of the Old and Main Town, [w:] Polish lands at the turn of the first and the second millennia, red. P. Urbańczyk, Warszawa, s. 15-32.

2004b Nowe źródła archeologiczne do dziejów wczesnośredniowiecznego Gdańska, [w:] Archeologia et historia urbana, red. R. Czaja i in., Elbląg, s. 165-173.

2006 Archeologia Gdańska w latach 1988-2005. The archaeology of Gdańsk'a new periodical from the Gdańsk Archaeological Museum, [w:] Archeologia, t. 1, s. 11-88.

2009 Archeologia Gdańska w latach 1988-2005. The archaeology of Gdańsk'a new periodical from the Gdańsk Archaeological Museum, [w:] Archeologia, t. 1, wydanie 2 poprawione, s. 11-88. 
Paner H., Borcowski Z.

1993 Gdańsk. Ulica Grodzka 6-7, St. 1, AZP: 12-44, Informator Archeologiczny. Badania rok 1989, Warszawa, s. 85.

Piaskowski J.

1960 Technika gdańskiego hutnictwa i kowalstwa żelaznego X-XIVw. na podstawie badań metaloznawczych, [w:] Gdańsk, t. 2.

Polak Z.

2009 Badania archeologiczne prowadzone przy ulicy Grodzkiej 17 w Gdańsku, na terenie dawnego grodu książęcego i zamku krzyżackiego, [w:] XVI Sesja Pomorzoznawcza, cz. 1: Od epoki kamienia do okresu wczesnośredniowiecznego, Acta Archaeologica Pomoranica 3, red. A. Janowski, K. Kowalski, S. Słowiński, Szczecin, s. 471-480.

Rębkowski M.

2001 Pierwsze lokacje miast $w$ księstwie zachodniopomorskim. Przemiany przestrzenne i kulturowe, Kołobrzeg.

Rulewicz M.

1994 Rybołówstwo Gdańska na tle ośrodków miejskich Pomorza od IX do XIII wieku, Wrocław.

Spors J.

1982 Lokalizacja miasta lokacyjnego na prawie lubeckim w Gdańsku w drugiej połowie XIII $i$ w początkach XIV wieku, Rocznik Gdański, t. 42, z. 1, s. 17-81.

Stephan W.

1911 Die Strassennahmen Danzigs, Quellen und Darstellungen zur Geschichte Westpreussens, t. 7, s. 5-10.

Susłowska W., Urbanowicz K.

1967 Szczątki ryb z wczesnośredniowiecznego Gdańska (X-XIII), [w:] Gdańsk, t. 6, s. 53-65.

Szyszka M.

2003 Badania ratunkowe w piwnicach Hali Targowejw Gdańsku, [w:] Dominikanie. Gdańsk-Polska - Europa, red. D. A. Dekański, A. Gołembnik, M. Grubka, Gdańsk-Pelplin, s. 485-499.

2009a Romański kościól pw.św. Mikołaja i trzynastowieczny zespót podominikański $w$ świetle badań archeologicznych na stan. 5 w Gdańsku, [w:] Architektura romańska w Polsce. Nowe odkrycia i interpretacje, red. T. Janiak, Gniezno, s. 610-640.

2009b Romański kościól pod wezwaniem świętego Mikołaja w świetle badań archeologicznych z 2001 i 2003 roku, [w:] Archeologia, t. 1, wydanie 2 poprawione, s. 105-136.

Szyszka M., Krzywdziński R.

2003 Badania ratownicze stanowiska u zbiegu ulicy Rajskiej i Heweliusza w Gdańsku (lata 1999-2000), [w:] XIII Sesja Pomorzoznawcza, t. 2: Od wczesnego średniowiecza do czasów nowożytnych, red. H. Paner, M. Fudziński, Gdańsk, s. $137-141$. 
Świechowski Z.

2000 Architektura romańska w Polsce, Warszawa.

Trzeciecka A., Trzeciecki M.

2002 Ceramika wczesnośredniowieczna z badań na terenie posesji Szklary 1 - Szklary 5, [w:] Dominikańskie Centrum św. Jacka w Gdańsku. Badania archeologiczne, t. 2, red. A. Gołembnik, Warszawa, s. 99-134.

Wapińska A.

1967 Materiały do wczesnośredniowiecznego bursztyniarstwa gdańskiego, [w:] Gdańsk, t. 6, s. 83-99.

Wiklak H.

1960 Obuwie gdańskie w X-XIII wieku, [w:] Gdańsk, t. 3, s. 7-104.

Zajączkowski S. M.

2002 Obowiązi ludności wiejskiej w Polsce w budownictwie obronnym do połowy $X V$ w., [w:] Budownictwo i budowniczowie w przeszłości, red. A. Abramowicz, J. Maik, Łódź, s. 399-427.

Zbierski A.

1958 Dotychczasowe wyniki badań archeologicznych w kościołach św. Mikołaja $i$ św. Katarzyny w Gdańsku, Rocznik Gdański, R. 15/16, s. 53-77.

1964 Port gdański na tle miasta w X-XIII wieku, [w:] Gdańsk, t. 5.

1975 Początki Głównego (Prawego) miasta w Gdańsku, Kwartalnik Historii Kultury Materialnej, R. 23, nr 1, s. 55-66.

1978a Rozwój przestrzenny Gdańska w IX-XIII wieku, [w:] Historia, s. 71-125.

1978b Ośrodek handlowy i portowy, [w:] Historia, s. 194-223.

1978c Kultura mieszkańców, [w:] Historia, s. 234-259.

2003 Gdańsk w okresie przybycia dominikanów w XIII w., [w:] Dominikanie. Gdańsk - Polska - Europa, red. D. A. Dekański, A. Gołembnik, M. Grubka, Gdańsk-Pelplin, s. 399-421.

\section{SPATIAL DEVELOPMENT OF EARLY MEDIEVAL GDAŃSK IN THE LIGHT OF ARCHAEOLOGICAL SOURCES}

Summary

Gdańsk is situated on Gdańsk Bay at the mouth of the Motława River at the confluence with the Vistula River, about $4.5 \mathrm{~km}$ from the Baltic Sea coast. Gdańsk Bay is protected from the open sea by the Hel Peninsula that stretches over $30 \mathrm{~km}$, creating ideal conditions for operating a seaport. The oldest traces of early medieval settlement were recorded in the area of Długi Targ Street under the town hall of the main town. Dendrochronological analyses proved that the oldest wooden structures in this region can be dated to the $930 \mathrm{~s}$. In the 1060s, at the confluence of the Motława and the Vistula Rivers a stronghold was built, which was also the seat of the local duke. This stronghold, with a surface area of 2.25 hectares, was surrounded by earthen and wooden ramparts, about 14 meters wide at the base. The results of recent studies indicate that the collapse of this edifice should be dated to the turn of the $12^{\text {th }}$ century or the beginning of the $13^{\text {th }}$ century. 
Within the Old Town, in the areas of the streets of Podwale Staromiejskie, Oborniki Olejarna, Igielnicka and Tartaczna, compact built-up zones appeared about the mid-1 $2^{\text {th }}$ century. At that time numerous dwellings and craft workshops; mainly shoemaker, tanning and bone and antler production ones were erected. These were built using the log construction, post-and-plank construction methods and, less frequently, the wattle construction one. In the vicinity of the Wielki Młyn (the Great Mill), on the mill islet called Schild, three levels of wooden streets and the remains of houses dated to the years 1230-1301, while under this edifice traces of settlement from the $11^{\text {th }}$ and the $13^{\text {th }}$ centuries were recorded. Settlement from the $12^{\text {th }}$ and the $13^{\text {th }}$ centuries was also discovered in the area of Rajska Street and Heweliusza Street. Near St Nicholas' church, at the large square, probably of a market place nature, settlements from the $10^{\text {th }}$ century were recorded. Under the building of the Market Hall, the site of a former Dominican monastery, a settlement from the $10^{\text {th }}$ century, a cemetery dated from the second half of the $10^{\text {th }}$ century and the remains of two Romanesque churches were discovered. The older of the churches, $34.5 \mathrm{~m}$ long, with a semicircular apse, was built in the 1190 s, while the younger one, $40 \mathrm{~m}$ long, with a rectangular choir was erected on the older remains in the 1220s. In the second half of the $13^{\text {th }}$ century, the construction of the monastery began, the remains of which survived under the present Plac Dominikański (Dominican Square). There was one chamber with a quadripartite vault supported by a central pillar. This was renovated and currently it houses a subterranean exhibition. In the Main Town, apart from a small settlement in the area of Długi Targ Street, more intense traces of an early medieval settlement were not recorded. In this system, the location of Lübeck town, founded about 1260, should be suspected in the areas of the Old Town. 
